\title{
Analysis Of The Relevance Of Fiscal Decentralization In Ensuring Country Investment Attractiveness
}

\author{
https://doi.org/10.21272/sec.4(2).99-105.2020.
}

Ihor Molotok, ORCID: https://orcid.org/0000-0002-7392-6416

Sumy State University, Ukraine

\begin{abstract}
Over the last three decades, fiscal decentralization reform has become widespread in the world as one of the most effective tools for ensuring the efficient functioning of the public and local finances, as it involves the transfer of powers from central to local or regional levels of government under the principle of subsidiarity and more effective allocation of budgetary funds. However, despite the fact that the reform of fiscal decentralization is mainly aimed at a qualitative transformation of the functioning of the budgetary system, it is crucial to take into account the consequences and interrelations of this process with other components of economic policy and their target parameters when developing the concept and algorithm for its implementation. Thus, in particular, many empirical studies confirm the impact of fiscal federalism on country economic growth. However, it is also essential to identify the impact of reform on the parameters of the country investment attractiveness. In the article, empirical studies on the impact of decentralization on the country's and region's investment attractiveness indicators were analyzed. The analysis results revealed that this issue has not become widespread in the scientific literature, and the existing research does not allow a clear conclusion about the nature of the impact of decentralization on the parameters of investment activity. The paper provides panel data regression analysis in order to identify the impact of revenue and (cost) expenditure decentralization on net inflow of foreign direct investment, gross capital formation and business network density for a sample of 12 unitary European countries (Czech Republic, Denmark, Estonia, France, Hungary, Italy, Latvia, Lithuania, Poland, Slovak Republic, Slovenia, and Ukraine) for 2008-2018. According to the modeling results, it was found that the level of expenditure decentralization has a positive effect on the net inflow of foreign direct investment and business network density, negative - on the volume of gross capital formation. In contrast, revenue decentralization has no statistically significant effect on any of the performance parameters.
\end{abstract}

Keywords: expenditure (cost) decentralization, revenue decentralization, investment attractiveness, investment activity, regression analysis.

JEL Classification: C33, H30, E62, O16.

This work is licensed under a Creative Commons Attribution 4.0 International License.

Cite as: Molotok, I. (2020). Analysis Of The Relevance Of Fiscal Decentralization In Ensuring Country Investment Attractiveness. SocioEconomic Challenges, 4(2), 99-105. https://doi.org/10.21272/sec.4(2).99-105.2020.

(C) The Author, 2020. This article is published with open access at Sumy State University.

\section{Introduction}

Over the last few decades, the intensification of globalization and integration has led to the transformations in various spheres and parts of the economic system at the national and supranational levels. In particular, one of the areas that is actively reformed is relationships between the central and local governments. Thus, clarification of the impact of the reform of the financial (fiscal) federalism or fiscal decentralization has been becoming an important issue both at the theoretical and empirical levels. A key feature of the reform of fiscal decentralization is the effective redistribution of powers between levels of government, which naturally leads to the change in the structure of their expenditures. At the same time, it is impossible to achieve high efficiency of the implemented measures in the context of this reform without the formation of a strong financial base at the local community level. Thus, fiscal decentralization has two main projections - revenue decentralization and costs (expenditures) decentralization. The intensity and progress of the implementation of the reform in the context of both projections should be proportionate and balanced, as the existence of significant 
imbalances in this process not only threatens to undermine the effectiveness of the reform but may even exacerbate existing in the pre-reform period problems.

However, even though the reform of fiscal decentralization is mainly aimed at the qualitative transformation of the budget system, but in developing the concept and algorithm for its implementation, it is essential to take into account the consequences and relationships of this process with other components of economic policy and their targets. Thus, in particular, many empirical studies confirm the impact of fiscal federalism on country economic growth. However, it is also important to clarify the impact of the reform on the parameters of the investment attractiveness of the country.

\section{Literature review}

In order to understand key perspectives and hypotheses of the research, it is necessary to underline previous theoretical and empirical findings in this sphere. Thus, Kappeler et al. (2013) studied the impact of revenue decentralization on the dynamics of investments in regional infrastructure development based on a sample of 20 European countries for 1990-2009. Modeling using panel data analysis showed that the introduction of revenue decentralization led to increased investment in regional infrastructure. However, the effect of income decentralization decreases with an increasing use of grants to finance infrastructure projects.

Kis-Katos and Sjahrir (2014) also reached similar conclusions. Namely, they studied the experience of 271 administrative units in Indonesia during 1994-2009. In particular, researchers found out that after the implementation of the decentralization reform in regions with a traditionally low level of investment activity, there was a significant increase in public investment in infrastructure projects.

Burke et al. (2014) also note that fiscal decentralization leads to the intensification of investment processes due to the fact that local governments receive more of their own financial resources, which can be used to implement the most promising and important infrastructure projects. The authors also note that the identified patterns are more vital for middle-income countries. Moreover, Faguet (2005) also confirmed that the reform of fiscal decentralization in Bolivia and Colombia led to the intensification of investment processes.

However, Chaudhry and Hanif (2015), while analyzing the impact of fiscal decentralization on public investment on the example of Pakistan in 1972-2003, found that strengthening the fiscal autonomy of local governments has a positive effect on local budget revenues and is a trigger for public investment. At the same time, the growth of the share of both local budget revenues and their expenditures in the structure of similar indicators of the consolidated budget allows improving the level of public investment and macroeconomic indicators of the country.

In contrast, de Melo (2010), while studying the impact of fiscal decentralization on investment processes in Latin America, notes that the implementation of fiscal federalism constrains the scale of public investment in regional investment projects, but at the same time is a prerequisite for intensifying private investments. However, Gao et al. (2019), in terms of China's experience of fiscal decentralization impact on investment processes, also confirmed the positive impact on the dynamics of corporate investments. Thus, the study results showed that with an increase in the fiscal decentralization of local governments, new investments of firms under their jurisdiction also increase. In turn, encouraging excessive investment, fiscal federalism adversely affects the effectiveness of corporate investment. The obtained results show that the fiscal decentralization is a determinant of investment activity at the corporate level that expands the existing scientific outcomes in terms of the research of fiscal federalism impact on country economic development. Thus, the reform and its consequences might be taken into account during state economic policy formation.

Thus, a review of existing researches in the field allowed to underline a lack of empirical research aimed at the identification of the impact of fiscal decentralization on investment processes in the country or region, in contrast to researches about fiscal federalism impact on economic growth measures. In addition, the small number of existing research studies mainly focus on studying the experience of a particular country, rather than cross-country analysis, and reveal opposite and contradictory results.

Consequently, the lack of sufficient empirical research on clarification of the impact of fiscal decentralization on investment processes in the country, as well as their ambiguity, necessitates more in-depth and comprehensive further research. Thus, the main objective of this work is an empirical study on the impact of cost and revenue decentralization on the country's investment attractiveness. 


\section{Methodology and Results}

First, it should be noted that the realization of this goal would be carried out using panel data regression analysis in Stata software. In turn, the study will be conducted for a sample of countries including 12 unitary European countries (the Czech Republic, Denmark, Estonia, France, Hungary, Italy, Latvia, Lithuania, Poland, Slovak Republic, Slovenia, and Ukraine) for 2008-2018.

It is not surprising that the main independent variables are indicators of cost and revenue decentralization that calculated by the Organization for Economic Cooperation and Development (OECD, 2018) as the ratio of revenues (expenditures) of local budgets to revenues (expenditures) of the consolidated budget.

At the same time, a set of dependent variables consist of measurement indicators that allow characterizing the investment attractiveness of the country. Namely, Tkachenko (2018) mentioned that today international organizations and rating agencies provide some ratings and indices designed to directly or indirectly assess the dynamics of the investment attractiveness of the country. Specifically, the author highlights the International Business Compass, Investment Climate Survey, the Global Competitiveness Index, etc. In the research, the outcomes of rating agencies such as European Business Association, Institutional Investor, Euromoney, Moody's Investors Service, UNCTAD, Heritage Foundation, Business Environment Risk Intelligence, and others are mentioned. However, it is fair to note that the most visible evidence of the attractiveness of territory for investors is the amount of investment (Tkachenko also analyzes this indicator in his study). Considering the above mentioned, the level of investment attractiveness of the country is proposed to be assessed through such performance variables as net inflow of foreign direct investment, US Dollars (FDI), gross capital formation, US Dollars (GCF ) and the density of the business network, calculated as the volume of new registered business entities per 1,000 people aged 15 to 64 (Dens). Each of the dependent indicators will be used in two models in the context of testing the hypothesis about the impact on it separately cost and revenue decentralization, i.e. in total 6 regression models will be built within this study.

Moreover, given the fact that each model has only one independent variable in order to improve the quality of the modeling the set of other independent variables will be used as so-called control variables. Thus, the list of these variables includes consumer price index $(2010=100 \%)(\mathrm{CPI})$; current account balance (US Dollars) $(\mathrm{CAB})$; the ratio of the employed population to the total population, $15+(\%$, according to the methodology of the International Labor Organization) (Empl); trade turnover (\% of GDP) (Trade); GDP growth rate, \% (GDPg). All these indicators were accumulated from the World Development Indicators collection of the World Bank group database.

Thus, the results of regression modeling of the impact of cost decentralization on the net inflow of foreign direct investment are presented in table 1.

Table 1. The results of regression modeling of the impact of cost decentralization on the net inflow of foreign direct investment

\begin{tabular}{|l|c|c|c|c|c|}
\hline FDI & Coefficient & Standard error & t-value & p-value & Significance \\
\hline Exp & 171000000,000 & 106000000,000 & 1,61 & 0,107 & $*$ \\
\hline CAB & $-0,146$ & 0,053 & $-2,77$ & 0,006 & $* * *$ \\
\hline Empl & 539000000,000 & 217000000,000 & 2,49 & 0,013 & $* *$ \\
\hline GDPg & $-636000000,000$ & 230000000,000 & $-2,77$ & 0,006 & $* * *$ \\
\hline GCF & 0,079 & 0,009 & 8,81 & 0,000 & $* * *$ \\
\hline Dens & 265000000,000 & 235000000,000 & 1,13 & 0,260 & \\
\hline Trade & 138000000,000 & 49800000,000 & 2,77 & 0,006 & $* * *$ \\
\hline Constant & $-53800000000,000$ & 10800000000,000 & $-4,99$ & 0,000 & $* * *$ \\
\hline
\end{tabular}

Notes: Exp - indicator of cost decentralization calculated as the ratio of local budget expenditures to the consolidated budget expenditures of the country, $\%$; level of statistical significance at one of the confidence intervals: *** $\mathrm{p}<0,1, * * \mathrm{p}<0,05, * \mathrm{p}<0,1$.

Thus, considering panel data regression results, first of all, it should be noted that the level of statistical significance of the model as a whole can be assessed as satisfactory because the coefficient of determination is 0.591 , which allows us to conclude that the variation of net inflow of foreign direct investment by $59.1 \%$ is due to variation factor (control) variables. However, most independent variables are also statistically significant at one of three confidence intervals $(99 \%, 95 \%$, or $90 \%)$. The only variable that is not characterized by the presence of a statistically significant relationship with the dependent variable is the density of the 
business network, i.e. in the process of foreign direct investment attracting is important not so much the presence of a significant number of business units in the country, but quality and efficiency of their activity.

However, it was found that the factors of negative impact on the net inflow of foreign direct investment are the current account balance and GDP growth, which can be explained as follows: in stable macroeconomic dynamics in the country, domestic businesses do not need to actively attract foreign direct investment, however, at the same time, there is a possibility of expansion of own business network abroad. In turn, other significant factors have a positive effect on the dynamics of the dependent variable, namely: an increase in employment by $1 \%$ leads to an increase in net inflows of foreign direct investment by 539 million USD; growth by 1 USD of gross capital formation causes an increase in the dependent parameter by 0,079 USD; an increase of $1 \%$ in the share of exports and imports in GDP causes an increase in the dependent variable by 138 USD. In addition, the results of the regression analysis confirmed one of the hypotheses of this study, namely: an increase in the level of cost decentralization by $1 \%$ with a $90 \%$ probability will lead in increase of the net inflow of foreign direct investment by 171 million USD.

In turn, the results of regression modeling of the impact of revenue decentralization on the net inflow of foreign direct investment are given in table 2 .

Table 2. Results of regression modeling of the impact of revenue decentralization on the net inflow of foreign direct investment

\begin{tabular}{|l|c|c|c|c|c|}
\hline FDI & Coefficient & Standard error & t-value & p-value & Significance \\
\hline Rev & 142000000,000 & 173000000,000 & 0,82 & 0,412 & \\
\hline CAB & $-0,132$ & 0,052 & $-2,53$ & 0,011 & $* *$ \\
\hline Empl & 635000000,000 & 209000000,000 & 3,04 & 0,002 & $* * *$ \\
\hline GDPg & $-614000000,000$ & 232000000,000 & $-2,65$ & 0,008 & $* * *$ \\
\hline GCF & 0,074 & 0,008 & 8,93 & 0,000 & $* *$ \\
\hline Dens & 291000000,000 & 245000000,000 & 1,18 & 0,236 & \\
\hline Trade & 107000000,000 & 46900000,000 & 2,28 & 0,023 & $* *$ \\
\hline Constant & $-51300000000,000$ & 10900000000,000 & $-4,72$ & 0,000 & $* *$ \\
\hline
\end{tabular}

Notes: Rev - indicator of revenue decentralization, calculated as the ratio of local budget revenues to revenues of the consolidated budget of the country, $\%$; level of statistical significance at one of the confidence intervals: $* * * \mathrm{p}<0,1$, $* * \mathrm{p}<0,05, * \mathrm{p}<0,1$.

Based on the modeling results, it should be noted that the second model (Table 2) has a few points lower the coefficient of determination (0.584). However, this result is still considered acceptable in economic and mathematical modeling. Despite the general similarity of the results of the regression analysis (similarly to the first model, block of factors of the negative impact include the current account balance and GDP growth, no statistically significant effect of business network density on the dependent variable, other significant factor variables have a positive impact on net foreign direct investment; in general, the values of the coefficients of the model differ insignificantly), within the framework of this block of study the hypothesis of the relationship between the level of revenue decentralization and net inflow of foreign direct investment is not confirmed.

The following two tables contain the results of regression modeling on the impact of cost decentralization (Table 3) and revenue decentralization (Table 4) on gross capital formation.

Table 3. The results of regression modeling of the impact of cost decentralization on gross capital formation

\begin{tabular}{|l|c|c|c|c|c|}
\hline GCF & Coefficient & Standard error & t-value & p-value & Significance \\
\hline Exp & $-2050000000,000$ & 1010000000,000 & $-2,03$ & 0,042 & $* *$ \\
\hline CAB & $-0,785$ & 0,201 & $-3,91$ & 0,000 & $* * *$ \\
\hline Empl & $-785000000,000$ & 1390000000,000 & $-0,56$ & 0,573 & \\
\hline GDPg & 3140000000,000 & 852000000,000 & 3,69 & 0,000 & $* * *$ \\
\hline FDI & 1,082 & 0,290 & 3,73 & 0,000 & $* * *$ \\
\hline CPI & $-9500000,000$ & 156000000,000 & $-0,06$ & 0,951 & \\
\hline Trade & $-1480000000,000$ & 276000000,000 & $-5,38$ & 0,000 & $* * *$ \\
\hline Constant & 378000000000,000 & 77300000000,000 & 4,89 & 0,000 & $* * *$ \\
\hline
\end{tabular}

Notes: Exp - indicator of cost decentralization calculated as the ratio of local budget expenditures to the consolidated budget expenditures of the country, $\%$; level of statistical significance at one of the confidence intervals: *** $\mathrm{p}<0,1, * * \mathrm{p}<0,05, * \mathrm{p}<0,1$. 
While it was confirmed that there is a statistically significant direct (positive) relationship between such variables as GDP growth (growth of the independent variable by $1 \%$ causes an increase in gross capital formation by 3,14 billion USD) and net inflow of foreign direct investment (growth of factor by 1 USD leads to an increase in the dependent variable by 1,082 USD). In addition, such control variables as the current account balance and turnover have a negative impact on the dynamics of gross capital formation. In turn, in contrast to the model given in table 1, it is confirmed the hypothesis of the existence of relationships between cost decentralization and gross capital formation, namely: an increase of the cost decentralization by $1 \%$ with a $95 \%$ probability will reduce gross capital formation by 2,05 billion USD. Thus, despite the positive impact of the level of cost decentralization on the net inflow of foreign direct investment, its effect on the dynamics of gross capital formation is the opposite.

Table 4. The results of regression modeling of the impact of revenue decentralization on gross capital formation

\begin{tabular}{|l|c|c|c|c|c|}
\hline GCF & Coefficient & Standard error & t-value & p-value & Significance \\
\hline Rev & $-51100000,000$ & 1910000000,000 & $-0,03$ & 0,979 & \\
\hline CAB & $-0,794$ & 0,179 & $-4,44$ & 0,000 & $* * *$ \\
\hline Empl & $-438000000,000$ & 1300000000,000 & $-0,34$ & 0,735 & \\
\hline GDPg & 2520000000,000 & 812000000,000 & 3,11 & 0,002 & $* * *$ \\
\hline FDI & 0,942 & 0,262 & 3,60 & 0,000 & $* *$ \\
\hline Dens & $-451000000,000$ & 1500000000,000 & $-0,30$ & 0,764 & \\
\hline Trade & $-1020000000,000$ & 269000000,000 & $-3,78$ & 0,000 & $* * *$ \\
\hline Constant & 251000000000,000 & 75900000000,000 & 3,31 & 0,001 & $* * *$ \\
\hline
\end{tabular}

Notes: Rev - indicator of revenue decentralization, calculated as the ratio of local budget revenues to revenues of the consolidated budget of the country, $\%$; level of statistical significance at one of the confidence intervals: *** $\mathrm{p}<0,1, * * \mathrm{p}<0,05, * \mathrm{p}<0,1$.

In order to identify the impact of revenue decentralization on the volume of gross capital formation, the following conclusions can be drawn:

$>$ coefficient of determination of the model is 0.725 , which is quite high;

$>$ strength, character and significance of the relationship of control variables with the performance indicator are almost similar to those presented in table 4;

$>$ regression results do not confirm the hypothesis of a statistically significant relationship between the level of revenue decentralization and the volume of gross capital formation.

Table 5 and 6 show the results of regression modeling of the impact of cost decentralization (Table 5) and revenue decentralization (Table 6 ) on the business network density in the country.

In the context of formalizing the impact of decentralization parameters on the integrity of the business network in the country, it should be noted that despite the implementation of control variables, the adequacy of both models is critically low at $3.9 \%$ and $9.1 \%$, respectively, and therefore the results can not be considered as relevant (although in the model from Table 5 a positive and statistically significant effect of the level of cost decentralization on the business density was found).

Table 5. The results of regression modeling of the impact of cost decentralization on the density of the business network

\begin{tabular}{|l|c|c|c|c|c|}
\hline Dens & Coefficient & Standard error & t-value & p-value & Significance \\
\hline Exp & 0,155 & 0,072 & 2,16 & 0,031 & $* *$ \\
\hline CAB & 0,000 & 0,000 & 0,77 & 0,443 & \\
\hline Empl & 0,018 & 0,078 & 0,23 & 0,816 & \\
\hline GDPg & 0,129 & 0,047 & 2,74 & 0,006 & $* * *$ \\
\hline FDI & 0,000 & 0,000 & 0,48 & 0,634 & \\
\hline GCF & 0,000 & 0,000 & $-0,06$ & 0,956 & \\
\hline CPI & 0,006 & 0,010 & 0,64 & 0,521 & \\
\hline Trade & 0,022 & 0,017 & 1,28 & 0,200 & \\
\hline Constant & $-3,542$ & 5,117 & $-0,69$ & 0,489 & \\
\hline
\end{tabular}

Notes: Exp - indicator of cost decentralization calculated as the ratio of local budget expenditures to the consolidated budget expenditures of the country, $\%$; level of statistical significance at one of the confidence intervals: *** $\mathrm{p}<0,1, * * \mathrm{p}<0,05, * \mathrm{p}<0,1$. 
Table 6. The results of regression modeling of the impact of revenue decentralization on the density of the business network

\begin{tabular}{|l|c|c|c|c|c|}
\hline Dens & Coefficient & Standard error & t-value & p-value & Significance \\
\hline Rev & 0,020 & 0,138 & 0,15 & 0,883 & \\
\hline CAB & 0,000 & 0,000 & 0,36 & 0,715 & \\
\hline Empl & 0,002 & 0,079 & 0,03 & 0,977 & \\
\hline GDPg & 0,129 & 0,048 & 2,67 & 0,007 & $* * *$ \\
\hline FDI & 0,000 & 0,000 & 0,50 & 0,617 & \\
\hline GCF & 0,000 & 0,000 & $-0,20$ & 0,840 & \\
\hline CPI & 0,008 & 0,011 & 0,74 & 0,459 & \\
\hline Trade & 0,016 & 0,017 & 0,95 & 0,342 & \\
\hline Constant & 1,870 & 5,276 & 0,35 & 0,723 & \\
\hline
\end{tabular}

Notes: Rev - indicator of revenue decentralization, calculated as the ratio of local budget revenues to revenues of the consolidated budget of the country, \%; level of statistical significance at one of the confidence intervals: $* * * p<0,1, * * p<0,05, * p<0,1$.

\section{Conclusions, Discussion and Recommendations}

Thus, the study on the empirical formalization of the impact of cost and revenue decentralization on the parameters of investment attractiveness of the country (net inflow of foreign direct investment, gross capital formation and business network density) was only partially confirmed the study hypotheses. In particular, the positive impact of cost decentralization on the net inflow of foreign direct investment and the density of the business network was found. At the same time, the relationship with gross capital formation is negative. Instead, none of the models, where the main independent variable was the level of revenue decentralization, did not obtain statistically significant results on the impact on the parameters of the country investment attractiveness. Thus, it can be concluded that investment activity not so much more depends on the level of financial self-sufficiency of local governments, but on the freedom of subnational entities to finance expenditure powers independently from the central government. The identified results should be taken into account both in the context of the implementation of the reform of fiscal decentralization and in the process of formation and implementation of public investment policy.

\section{References}

1. Kappeler, A.; Solé-Ollé, A.; Stephan, A. and Välilä T. (2013). Does fiscal decentralization foster regional investment in productive infrastructure? Journal of Political Economy, 31, 15-25. https://doi.org/10.1016/j.ejpoleco.2013.03.003.

2. Kis-Katos, K.; Sjahrir, B. S. (2014). The Impact of Fiscal and Political Decentralization on Local Public Investments in Indonesia // IZA Discussion Papers. http://ftp.iza.org/dp7884.pdf.

3. Burke, A.; Kanapathy, V.; Hazri, H.; Phongpaichit, P. and Benyaapikul, P. (2014). Middle Income Trap: Economic Myth, Political Reality // Asia Foundation. https://asiafoundation.org/resources/pdfs/MiddleIncomeTrap.pdf.

4. Faguet, J. P. (2005). The Effects of Decentralisation on Public Investment: Evidence and Four Lessons from Bolivia and Colombia // LSE Crisis States Research Centre. - Retrieved from http://www.lse.ac.uk/international-development/Assets/Documents/PDFs/csrc-working-papers-phaseone/wp62-effects-of-decentralisation-on-public-investment.pdf.

5. Chaudhry, I.; Hanif, I. (2015). Interlinks of Fiscal Decentralization and Public Investment in Pakistan. Pakistan Journal of Commerce and Social Sciences, 9(3), 850-864. chromeextension://ohfgljdgelakfkefopgklcohadegdpjf/http://www.jespk.net/publications/265.pdf

6. De Mello, L. (2010). Fiscal Decentralisation and Public Investment: The Experience of Latin America // The Organisation for Economic Co-operation and Development. https://www.oecdilibrary.org/docserver/5km347r2hhbpen,pdf?expires $=1586912570 \&$ id=id\&accname=guest $\&$ checksum $=8$ F10E01747C89918E3E9AE53DFE7 $\underline{5524}$.

7. Gao, S.; Wang, L.; Liu, N. and Zhang, M. (2019). Fiscal decentralization and corporate investment: empirical evidence from China. Journal of Economic Policy Reform, 22(1), 5168. DOI: $10.1080 / 17487870.2017 .1310042$. 
8. OECD

http://www.oecd.org/ctp/federalism/oecdfiscaldecentralisationdatabase.htm\#C Title.

9. Tkachenko. O. (2018). Otsinka investytsiinoi pryvablyvosti Ukrainy kriz pryzmu mizhnarodnykh reitynhiv [Estimation of investment attractiveness of Ukraine through the prism of international ratings]. Investytsiyi: praktyka ta dosvid-Investments: practice and experience, 11, 15-21 [in Ukrainian]. http://www.investplan.com.ua/index.php?op=1\&z=6114\&i=2.

10. World Development Indicators (2018). https://databank.worldbank.org/source/world-developmentindicators\#. 